\title{
Możliwości wykorzystania przekazu satelitarnego w diagnozowaniu stanu technicznego trakcyjnych pojazdów szynowych
}

\begin{abstract}
Wniniejszym artykule przedstawiono potencjalne zastosowania satelitarnej transmisji danych $w$ obszarze diagnostyki trakcyjnych pojazdów szynowych, opisano rozwój telekomunikacji satelitarnej, a w szczególności satelitarnej radiokomunikacji ruchomej, scharakteryzowano system INMARSAT a także wybrany terminal satelitarny.

Artykut powstat na podstawie prac prowadzonych $w$ ramach projektu badawczego ,Zastosowanie satelitarnego systemu akwizycji danych do poligonowych badań spalinowych pojazdów szynowych" (nr 4 T12D 054 30) finansowanego przez Ministerstwo Nauki i Szkolnictwa Wyzszego.
\end{abstract}

\section{Wstęp}

\subsection{Systemy bezprzewodowej transmisji danych} Zdalna diagnostyka trakcyjnego pojazdu szynowego wymaga zastosowania systemu sterowania $\mathrm{z}$ zaimplementowanym algorytmem realizującym proces oceny stanu technicznego poszczególnych zespołów i podzespołów tego pojazdu. Wyniki tej oceny system sterowania powinien przesyłać do centrum diagnostycznego za pośrednictwem transmisji bezprzewodowej.

Transmisja bezprzewodowa jest jedynym możliwym sposobem transmisji danych w systemach, w których obiekt pomiaru przemieszcza się (np. w pojeździe) lub jest znacznie oddalony od centrali systemu pomiarowego (sondy meteorologiczne, obiekty kosmiczne) albo znajduje się w miejscu trudno dostępnym $[6,7]$.

Obecnie bezprzewodowa transmisja danych może być realizowana głównie poprzez:

- interfejs IrDA (ang. „Infrared Data Association") - interfejs wykorzystujący promieniowanie podczerwone umożliwiający transmisję danych z prędkością $4 \mathrm{Mb} / \mathrm{s}$ na odległość do $1 \mathrm{~m}$

- interfejs Bluetooth - interfejs radiowy pracujący w paśmie $2,45 \mathrm{GHz}$ umożliwiający transmisję danych z prędkością $1 \mathrm{Mb} / \mathrm{s}$ na odległość do $10 \mathrm{~m}$

- sieci telefonii komórkowej GSM (ang. „Global System for Mobile Communication")

- łącza satelitarne.

Dwa pierwsze wymienione rodzaje transmisji (IrDA i Bluetooth) umożliwiają przesyłanie danych na małe odległości i stosuje się je głównie w celu wyeliminowania połączeń przewodowych pomiędzy nadajnikiem a odbiornikiem, które znajdują się w bliskiej odległości od siebie. Ze względu na niewielki zasięg działania powyższych systemów nie mogą być one rozpatrywane $\mathrm{w}$ przypadku transmisji danych pomiędzy przemieszczającym się pojazdem a centrum diagnostycznym, czyli na odległości znacznie przekraczające zasięg działania wymienionych standardów.
Dwa kolejne rodzaje transmisji (sieci telefonii komórkowej GSM i łącza satelitarne) umożliwiają przesyłanie danych na rozległym obszarze obejmującym zasięg działania danego systemu łączności: w przypadku sieci GSM jest to zazwyczaj obszar danego kraju, natomiast w przypadku systemów satelitarnych może to być obszar danego kontynentu (np. system ESA obejmujący swym zasięgiem Europę) lub obszar całego globu (np. systemy Iridium, INMARSAT, Globalstar) [9].

Biorąc pod uwagę koszty zakupu aparatury nadawczo-odbiorczej oraz koszty przesyłania danych sieci GSM mają zdecydowaną przewagę nad systemami transmisji satelitarnej. Trzeba jednak zaznaczyć, że w warunkach polskich komercyjne sieci GSM nie oferują $100 \%$ pokrycia szlaku kolejowego, co jest istotnym mankamentem jeżeli transmisja danych ma odbywać się w trybie rzeczywistym lub jeżeli uszkodzenie pojazdu spowoduje jego zatrzymanie w miejscu pozbawionym zasięgu sieci GSM. Sytuacja taka jest często spotykana, ponieważ szlaki kolejowe często przebiegają przez tereny słabo zaludnione lub niezaludnione, na których brak jest infrastruktury GSM, co uniemożliwia prowadzenie zdalnej diagnostyki. Szczególnie do omawianego zastosowania nadawałby się kolejowy system GSM-R (ang. „,Global System for Mobile Communication - Rail"), który w Polsce jest jednak dopiero w początkowej fazie wdrażania.

Istotną przewagą systemów łączności satelitarnej z punktu widzenia użytkownika jest to, że nie wymagają one żadnej infrastruktury naziemnej a jedynie zakupu terminalu pracującego w danym systemie. Sprawia to, że systemy satelitarne stanowią doskonałą alternatywę dla innych systemów radiokomunikacyjnych w miejscach, w których brak jest przyłączy do sieci konwencjonalnych, a ich realizacja wiąże się ze znacznymi nakładami lub z trudnością uruchomienia $\mathrm{w}$ odpowiednio krótkim czasie [1]. 
Wobec powyższego jedynym na dzień dzisiejszy środkiem łączności zapewniającym transmisję danych diagnostycznych z pojazdu szynowego będącego w ruchu niezależnie od jego usytuowania na szlaku kolejowym pozostaje transmisja satelitarna. Dodatkowo terminale łączności satelitarne zazwyczaj wyposażone są w moduł GPS (ang. „Global Positioning System”), który umożliwia wyznaczenie pozycji, prędkości i kursu pojazdu w wybranym układzie odniesienia (np. współrzędnych geograficznych) oraz odbiór generowanego przez system GPS sygnału czasu wzorcowego.

\subsection{Lączność satelitarna}

Cechą charakterystyczną łączności satelitarnej jest zdolność wytworzenia jednoczesnych połączeń dla wszystkich użytkowników znajdujących się na powierzchni Ziemi, wskutek czego zapewnione jest świadczenie usług telekomunikacyjnych niezależnie od odległości oraz liczby abonentów. Odnosi się to zarówno do naziemnych obiektów stałych, jak i do obiektów ruchomych poruszających się na lądzie, morzu lub w powietrzu [1].

Głównym celem zastosowania transmisji satelitarnej jest przesyłanie danych diagnostycznych $\mathrm{z}$ systemu sterowania zainstalowanego na trakcyjnym pojeździe szynowym znajdującym się $\mathrm{w}$ ruchu, w dowolnym punkcie szlaku kolejowego do komputera pełniącego rolę centrum diagnostycznego (odbiór, przetwarzanie, prezentowanie $\mathrm{i}$ archiwizowanie danych). Komunikacja powinna być zapewniona także $\mathrm{w}$ drugą stronę, aby możliwe było przesyłanie z centrum diagnostycznego do systemu sterowania pojazdu np. żądań nadawania danych diagnostycznych, sygnałów sterujących lub odpowiednich nastaw danych wielkości.

Po analizie usług oferowanych przez poszczególnych operatorów systemów satelitarnych $\mathrm{w}$ świetle wymagań dotyczących transmisji danych $\mathrm{z}$ pojazdu znajdującego się w ruchu oraz kosztów zakupu sprzętu i transmisji danych zdecydowano o wyborze terminalu pracującego w systemie INMARSAT - system ten jako jedyny świadczy usługi łączności z obiektami ruchomymi (statki, samoloty, pojazdy naziemne) [5, $8]$.

\section{Potencjalne zastosowania transmisji satelitarnej w obszarze zdalnej diagnostyki trakcyjnych pojaz- dów szynowych}

\subsection{Wdrażanie nowych systemów sterowania}

W fazie wdrażania nowych systemów sterowania na trakcyjnych pojazdach szynowych na dane diagnostyczne składają się głównie sygnały wejściowe doprowadzone do sterownika PLC oraz generowane przez ten sterownik wyjściowe sygnały sterujące. Zebrane dane diagnostyczne pozwalają zanalizować poprawność przyjętych algorytmów sterowania oraz ich implementacji w sterowniku PLC [3].
Analiza zmian w czasie sygnałów wejściowych oraz generowanych na ich podstawie sygnałów wyjściowych wymaga gromadzenia ich wartości $\mathrm{z}$ określonym interwałem czasowym (najlepiej w każdym cyklu pracy sterownika), jednak pojemność pamięci sterownika nie pozwala na zapis tak dużej ilości danych, dlatego gromadzenie danych diagnostycznych przebiega następująco:

- sterownik PLC co określony przedział czasowy (wartość tego przedziału zależy od czasu wykonywania przez sterownik jednego cyklu programu, od objętości przesyłanej ramki danych oraz od prędkości transmisji) tworzy ramkę danych diagnostycznych (wielkość ramki zależy od złożoności systemu sterowania - głównie od ilości wejść i wyjść) i przesyła ją za pośrednictwem interfejsu RS-232 do komputera serwisowego (odpowiednio oprogramowanego komputera przenośnego)

- odpowiednia aplikacja uruchomiona na komputerze serwisowym odbiera kolejne ramki danych diagnostycznych z jego portu szeregowego i gromadzi je na twardym dysku komputera jako kolejne wiersze pliku tekstowego.

Powyższa metoda bazuje na transmisji przewodowej i wymaga obecności na pojeździe odpowiednio przeszkolonego pracownika wyposażonego w odpowiednio oprogramowany komputer serwisowy. Zastosowanie transmisji satelitarnej wyeliminowałoby konieczność przebywania na pojeździe pracownika oddelegowanego jedynie $w$ celu zebrania danych diagnostycznych z pojazdu znajdującego się często kilkaset kilometrów od siedziby firmy. Pozwoliłoby to na zminimalizowanie kosztów badań i racjonalne wykorzystanie zasobów ludzkich (czasu pracy pracowników).

\subsection{Eksploatacja obserwowana}

Podczas eksploatacji obserwowanej mogą ujawnić się nieprawidłowości w pracy danego systemu lub samego systemu sterowania. Często nieprawidłowości te występują sporadycznie (np. raz na tydzień) w związku z czym ich przyczyna jest trudna do wykrycia. W takiej sytuacji algorytm uzbraja się w „pułapki” wychwytujące moment zaistnienie nieprawidłowości i tworzące historię przebiegu sygnałów wokół tego punktu (np. $5 \mathrm{~s}$ przed i $5 \mathrm{~s}$ po wystąpieniu nieprawidłowości). W tym przypadku ramka danych diagnostycznych zawiera tylko wybrane sygnały, których analiza pozwala na znalezienie przyczyn nieprawidłowości. Prowadzi to do uzyskania obiektywnych danych pomiarowych zamiast subiektywnych wrażeń personelu obsługującego pojazd.

Dla przykładu zostanie omówione badanie układu przeciwpoślizgowego na zmodernizowanych lokomotywach ST44 serii 3000 (rys. 1). Lokomotywy 
te mają 2 wózki 3-osiowe. Dane diagnostyczne zawierały: wartości prędkości poszczególnych osi lokomotywy, wartość prędkości referencyjnej, średnią wartość prędkości 4-ech osi (po odrzuceniu skrajnych wartości prędkości) oraz sygnały sterujące zaworami przeciwpoślizgowymi.

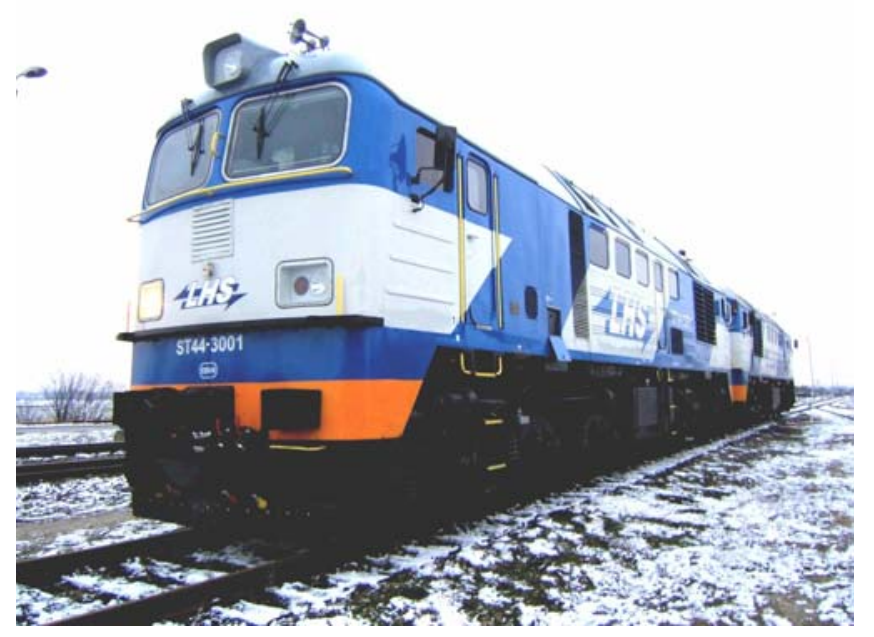

Rys. 1. Zmodernizowane lokomotywy ST44 serii 3000 (3001 oraz 3002) należące do PKP Linia Hutnicza Szerokotorowa spółka z o. o.

Program działania sterownika tego układu został „uzbrojony” w mechanizm, który rejestruje wystąpienie następujących zdarzeń (rys. 2):

- zdarzenie 1: zbiorczy sygnał poślizgu (będący sumą logiczną sygnałów poślizgu poszczególnych osi) trwa co najmniej $2 \mathrm{~s}$

- zdarzenie 2: w czasie $3 \mathrm{~s}$ wystąpią 4 poślizgi dowolnych osi

- zdarzenie 3: występuje poślizg co najmniej 4ech osi jednocześnie.
Ograniczona pojemność pamięci sterownika nie pozwala na zapis zbyt dużej ilości danych, wobec czego dla każdego z powyższych zdarzeń zarezerwowano obszar pamięci sterownika umożliwiający zarejestrowanie stanu wymienionych sygnałów w okresie $2 \mathrm{~s}$ przed i $2 \mathrm{~s}$ po wystapieniu danego zdarzenia (rys. 2). Niestety obszary te są „nadpisywane” po kolejnym wystapieniu danego zdarzenia. Zastosowanie transmisji satelitarnej umożliwiłoby rejestrację wszystkich wystapień omawianych zdarzeń a tym samym pełniejszą analizę zjawiska. Wyeliminowałoby również konieczność przebywania na pojeździe personelu gromadzącego dane diagnostyczne w sposób omówiony w poprzednim podpunkcie (na twardym dysku komputera za pośrednictwem interfejsu RS-232), tym bardziej, że uchwycenie nieprawidłowości (zebranie danych diagnostycznych) może okazać się bardzo czasochłonne zważywszy na przypadkowy charakter ich występowania.

\subsection{Normalna eksploatacja}

Podczas normalnej eksploatacji pojazdu trakcyjnego można zmniejszyć ilość przesyłanych danych diagnostycznych lub ograniczyć się jedynie do przesyłania tzw. alarmów informujących np. o uszkodzeniu danego czujnika. Dzięki zastosowaniu transmisji satelitarnej alarmy takie byłyby przesyłane do centrum diagnostycznego znajdującego się w lokomotywowni w wyniku czego personel warsztatowy otrzymywałby informację o rodzaju uszkodzenia jeszcze przed zjazdem pojazdu ze szlaku. Umożliwiłoby to np. wcześniejsze przygotowanie stanowiska naprawczego oraz odpowiednich narzędzi i części, skracając tym samym czas wyłączenia pojazdu z ruchu.

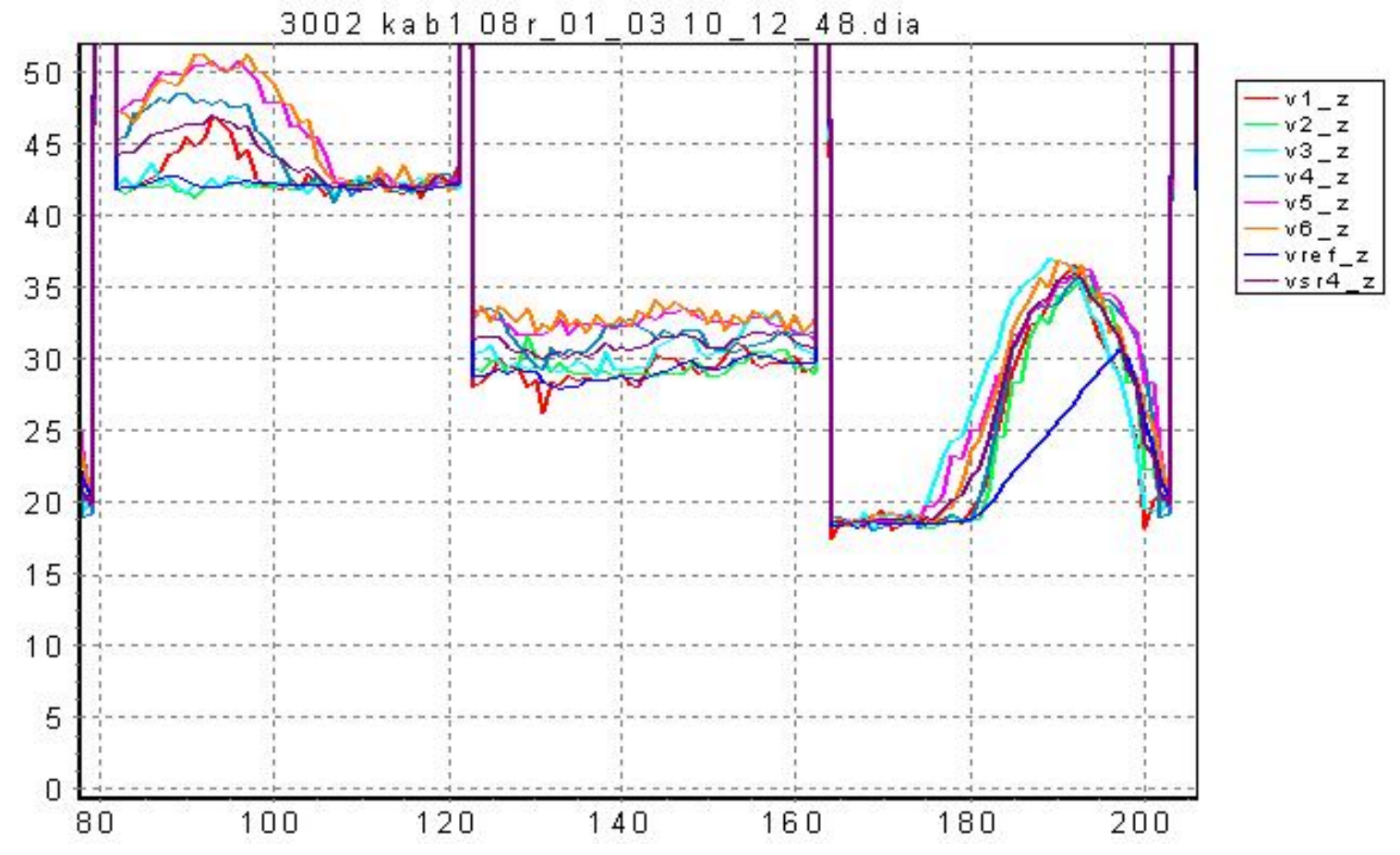

Rys. 2. Badanie działania układu przeciwpoślizgowego lokomotyw ST44 serii 3000 - rejestracja wybranych zdarzeń 


\section{Rozwój telekomunikacji satelitarnej}

W latach 50-tych XX wieku zarówno Stany Zjednoczone jak i ZSRR dysponowały rakietami zdolnymi wynieść satelitę w kosmos. Z okazji ogłoszonego od 1 lipca 1957 roku do 31 grudnia 1958 roku Międzynarodowego Roku Geofizycznego oba państwa zamierzały umieścić satelitę na orbicie. Jako pierwszym udało się to Rosjanom [29].

Era kosmiczna rozpoczęła się 4 października 1957 roku o godzinie 19:28, gdy z kosmodromu Bajkonur w ówczesnym Związku Radzieckim (obecnie w Kazachstanie) wystartowała rakieta R-7 z pierwszym sztucznym satelitą Ziemi o nazwie „Sputnik 1” (z języka rosyjskiego „towarzysz podróży”). Wydarzenie to stało się początkiem trwającego nieprzerwanie od ponad pięciu dekad „wyścigu w kosmos” [22].

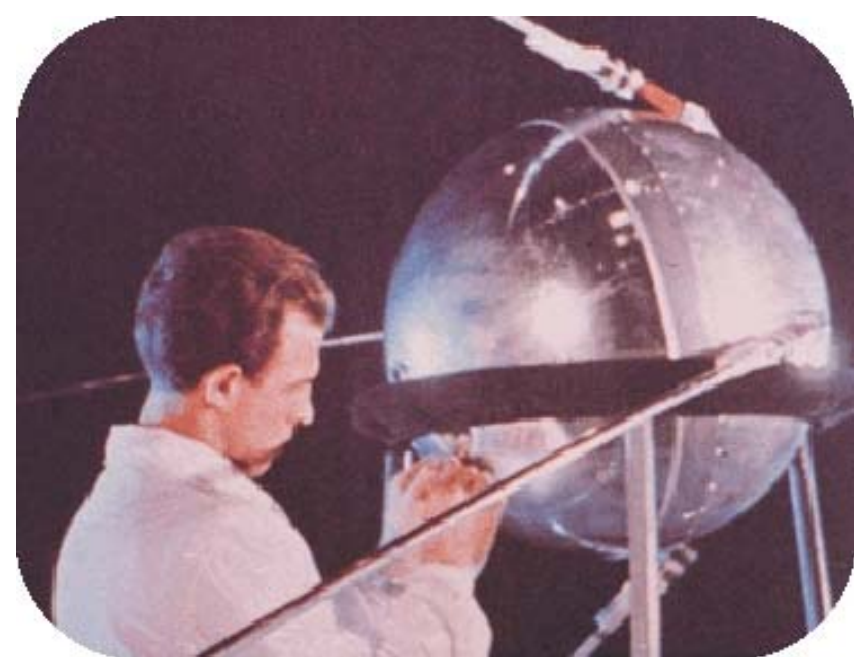

Rys. 3. „Sputnik 1”- pierwszy sztuczny satelita Ziemi wg [26]

„Sputnik 1” (rys. 3) był obiektem w kształcie kuli o średnicy $58,5 \mathrm{~cm}$ i wadze $83,6 \mathrm{~kg}$. Aby zbytnio się nie nagrzewał jego powłokę zewnętrzną wykonano $\mathrm{z}$ wypolerowanego aluminium o grubości $2 \mathrm{~mm}$, które odbijało promienie słoneczne. Satelita krążył po orbicie oddalonej o $250 \mathrm{~km}$ od powierzchni Ziemi przez trzy miesiace. W dniu 4 stycznia 1958 roku wyczerpały mu się baterie (srebrno-cynkowe) i spłonął w atmosferze. Podczas każdego obiegu wokół Ziemi, który trwał ok. 98 minut, satelita przemierzal prawie 48 tys. $\mathrm{km}$ z prędkością $8 \mathrm{~km} / \mathrm{s}$. „Towarzysz podróży” wyposażony był w 2 nadajniki oraz 4 anteny, które trzy razy w ciagu sekundy emitowały sygnały radiowe o częstotliwościach $20 \mathrm{MHz}$ i $40 \mathrm{MHz}$. Sygnały te mogli odbierać radioamatorzy na powierzchni Ziemi. Niosły ze sobą informację o temperaturze i ciśnieniu w przestrzeni kosmicznej. Pomogły również naukowcom w badaniu gęstości elektronów w jonosferze [17, 19, 27, 29, 31].

Rozwój sztucznych satelitów był niezwykle szybki. W ciagu kilku lat, poza badawczymi, pojawiły się liczne sztuczne satelity służące celom praktycznym. W dniu 1 kwietnia 1960 roku wydział administracji rządowej USA zajmujący się amerykańskim programem kosmicznym oraz rozwojem techniki lotniczej - Narodowa Agencja Aeronautyki i Przestrzeni Kosmicznej NASA (ang. „National Aeronautics and Space Administration") - umieściła na orbicie pierwszego w historii satelite meteorologicznego „TIROS 1” (ang. „Television InfraRed Observational Satellite"). Był to satelita do obserwacji telewizyjnych i podczerwonych. Przesłał on pierwsze zdjęcia Ziemi widzianej z kosmosu [14, 21, 31].

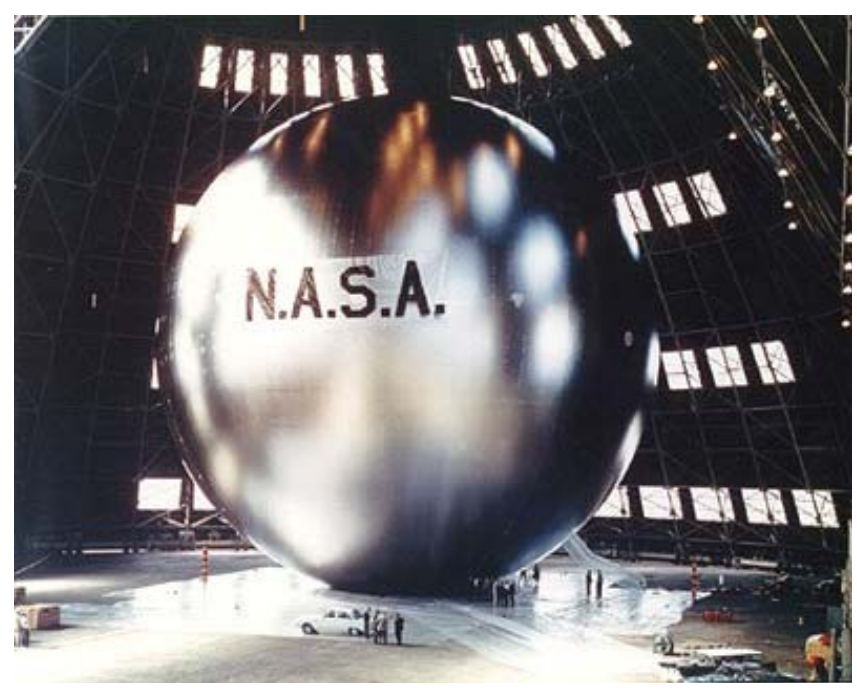

Rys. 4. Satelita „Echo 1A” wg [16]

W tym samym roku NASA przeprowadziła próby z pierwszymi sztucznymi satelitami telekomunikacyjnymi pasywnymi (biernymi) o nazwie „Echo”. Były to balony o średnicy $30 \mathrm{~m}$ wykonane z mylaru (aluminiowanego poliestru), które jedynie odbijały sygnały radiowe emitowane z Ziemi. W dniu 13 maja 1960 wystrzelono satelite „Echo 1” jednak z powodu awarii rakiety nośnej nie osiagnął on orbity. Zaplanowaną dla niego misję wykonał bliźniaczy satelita „Echo 1A” (rys. 4), którego wystrzelono 12 sierpnia 1960 roku. Dokonano wówczas pierwszej transmisji sygnałów telefonicznych i telewizyjnych między stacjami naziemnymi stosując częstotliwości $1 \mathrm{GHz}$ i 2,5 GHz. „Echo 1A” był widzialny z Ziemi nieuzbrojonym okiem i był prawdopodobnie najliczniej oglądanym obiektem pochodzenia ziemskiego wystrzelonym w kosmos $[2,14,15,16]$.

W dniu 4 października 1960 roku NASA wprowadziła na orbitę pierwszego eksperymentalnego satelite telekomunikacyjnego aktywnego (czynnego) „Courier 1B”. Odebrane z Ziemi sygnały zapisywane były $\mathrm{w}$ pamięci magnetycznej satelity a następnie retransmitowane po otrzymaniu przez niego odpowiedniego rozkazu. Na pokładzie satelity aktywnego znajduje się tzw. transponder - urządzenie elektroniczne, które odbiera sygnały przychodzące z Ziemi, 
wzmacnia je, przesuwa do innego pasma częstotliwości i po ponownym wzmocnieniu wysyła $z$ powrotem w kierunku Ziemi.

W dniu 10 lipca 1962 roku NASA wystrzeliła satelitę telekomunikacyjnego ,Telstar 1". Był to pierwszy satelita zaprojektowany od podstaw do transmisji połączeń telefonicznych i przesyłu danych (obrazów telewizyjnych, sygnałów telegraficznych oraz radiowych). Umożliwiał on retransmismisję pomiędzy Europą i USA 240 kanałów telefonicznych albo zamiennie jednego kanału telewizyjnego. Obecnie satelity najnowszej generacji, po ponad 50-ciu latach intensywnego rozwoju techniki łączności satelitarnej oraz elektroniki, są w stanie retransmitować do 22500 kanałów telefonicznych [20].

W dniu 6 kwietnia 1965 roku Międzynarodowa Organizacja Telekomunikacji Satelitarnej INTELSAT (ang. „INternational TELecommunications SATellite Consortium") umieściła na orbicie pierwszego komercyjnego satelitę telekomunikacyjnego noszący nazwę „Early Bird” (inne nazwy to „INTELSAT I” i „Atlantic I”). Był to satelita geostacjonarny do realizacji łączności pomiędzy Europą a Ameryką [18].

Od momentu powstania systemy łączności satelitarnej skupiały się na transmisji sygnałów telefonicznych i programów telewizyjnych. W latach 70tych XX wieku systemy te uzyskały monopol na połączenia międzykontynentalne. Sytuacja ta zmieniła się diametralnie w 1988 roku, gdy położono pierwszy kabel światłowodowy między Europą a Ameryką. Ze względu na znacznie większą pojemność światłowody zaczęły wypierać systemy satelitarne z tego segmentu rynku i obecnie systemy satelitarne traktowane są głównie jako systemy rezerwowe [5].

\section{Rozwój satelitarnej radiokomunikacji rucho- mej wg $[1,5]$}

Początkowo satelitarna radiokomunikacja ruchoma rozwijała się w ramach systemów morskich. Pierwsza sieć satelitarna do łączności ze statkami została włączona do eksploatacji przez Międzynarodową Organizację Morskiej Łączności Satelitarnej INMARSAT (ang. „INternational MARitime SATellite Organization") w 1982 roku. Choć początkowo terminale systemu charakteryzowały się wysoką ceną i dużymi rozmiarami to rynek satelitarnej telekomunikacji morskiej rozwinął się bardzo szybko. Ocenia się, że do 1995 roku uruchomiono ponad 24000 terminali tego systemu.

Jednocześnie prowadzono prace nad rozwiązaniami pozwalającymi na realizację połączeń fonicznych z pasażerami samolotów. Pierwszy taki system został uruchomiony w 1989 roku przez Skyphone. Obejmuje on swym zasięgiem wschodnie rejony USA, obszar Atlantyku, Europy, Afryki i część rejonu Środkowego Wschodu. Połączenia w systemie realizowane są przy wykorzystaniu satelity INMARSAT. W 1990 roku INMARSAT samodzielnie przystapił do realizacji tego rodzaju usług zarówno dla pasażerów, jak i obsługi linii lotniczych.

Dotychczas najsłabiej rozwijały się publiczne systemy satelitarne do łączności z obiektami poruszającymi się na lądzie. Pierwotnie były one wykorzystywane przez organizacje humanitarne oraz środki masowego przekazu w sytuacjach, gdy nie mogły być użyte konwencjonalne środki łączności. Znacznie szybciej następował rozwój militarnych systemów radiokomunikacji satelitarnej. Oprócz systemów łączności strategicznej, których przykładami są amerykański DSCS (ang. „Defense Satellite Communication System"), brytyjski SKYNET czy NATO SATCOM, rozwinęły się systemy taktyczne, jak np. amerykański TACSAT (ang. „TACtical SATellite System”). Z istoty swego przeznaczenia umożliwiają one komunikowanie się nie tylko z obiektami o stałej lokalizacji, lecz także z pojedynczymi samolotami, okrętami a nawet z najmniejszymi pododdziałami różnych rodzajów wojsk.

Na przełomie lat 80-tych i 90-tych XX wieku rozpoczęto prace nad satelitarnymi systemami telefonii komórkowej, zakładającymi wykorzystanie satelitów na orbitach niższych niż orbita geostacjonarna. Satelita na niskiej orbicie porusza się względem powierzchni Ziemi i oświetla znacznie mniejszy obszar niż satelita geostacjonarny, więc aby zapewnić ciagłą łączność między systemem satelitarnym a użytkownikiem konieczne jest zastosowanie konstelacji wielu satelitów i przełączanie połączeń między nimi (ang. „handover”), gdy satelita znika z pola widzenia terminalu naziemnego. Jest to sytuacja analogiczna do naziemnych systemów komórkowych, lecz tu użytkownik może być traktowany jako obiekt nieruchomy, a poruszają się stacje bazowe tworzące poszczególne komórki. Opierając się na powyższej koncepcji opracowano i uruchomiono systemy satelitarnej telefonii komórkowej Iridium i Globalstar, ale problemy związane $\mathrm{z}$ małym zapotrzebowaniem na usługi tego typu zatrzymały prace nad kolejnymi systemami. Nie przewidziano sukcesu telefonii naziemnej, głównie GSM, która dzięki usługom roamingu międzynarodowego zapewnia prawie globalny zasięg przy znacznie mniejszych kosztach oraz mniejszych i lżejszych terminalach niż w systemach satelitarnych.

Rozwój technologiczny końca lat 90-tych XX wieku pozwolił na realizację systemów satelitarnej telefonii komórkowej w oparciu o satelity na orbicie geostacjonarnej. Odpowiada to sytuacji naziemnej sieci komórkowej, gdzie wszystkie stacje bazowe zostały wyniesione na pokład satelity. Satelita taki musi transmitować w kierunku Ziemi sygnał odpowiednio dużej mocy, tak aby można było go odebrać przy pomocy przenośnego terminalu wielkości klasycznego telefonu komórkowego $\mathrm{z}$ niewielką anteną o dookólnej (wielokierunkowej) charakterystyce promieniowania. Satelita taki jest najbardziej zaawanso- 
wanym technologicznie urządzeniem wyposażonym w anteny o wymiarach rzędu kilkunastu metrów, mikrofalowe wzmacniacze mocy i cyfrowe układy przetwarzania sygnałów. Koszt budowy takiego satelity to około 1 mld USD. Według tej koncepcji powstały systemy Thuraya i ACeS, które rozpoczęły pracę w 2000 roku.

Rewolucja informacyjna obserwowana od początku lat 90-tych XX wieku zapoczątkowała ewolucję systemów satelitarnych w kierunku szerokopasmowych systemów transmisji danych multimedialnych. Systemy satelitarne wykorzystywane są do realizacji szybkiego dostępu do Internetu dla użytkowników, którzy nie mają dostępu do usług systemów naziemnych.

W rozwoju satelitarnych systemów łączności można zaobserwować stałą tendencję wzrostu komplikacji układów satelity (zwiększenie transmitowanej mocy, większe anteny, obróbka i przetwarzanie sygnałów na pokładzie satelity) prowadząca do możliwości zastosowania mniejszych i tańszych terminali naziemnych (przenośnych i ruchomych). Jednocześnie w celu zwiększenia pojemności systemów satelitarnych stosuje się zwielokrotnianie przestrzenne i polaryzacyjne sygnałów nadawanych w tych samych pasmach częstotliwości. W ostatnich latach zaczęto również stosować anteny wielowiązkowe $\mathrm{z}$ dynamicznie sterowanymi charakterystykami promieniowania oraz realizować transmisje w paśmie $(20 \div 30)$ $\mathrm{GHz}$.

Ostatnie sondaże wskazują na potencjalnie duże zapotrzebowanie na komercyjną sieć satelitarnej radiokomunikacji ruchomej. Wiele organizacji handlowych i przemysłowych oraz ludzi biznesu potrzebuje dostępu do usług telekomunikacyjnych w miejscach, w których brak jest przyłączy do sieci konwencjonalnych, a ich realizacja albo wiąże się ze znacznymi nakładami, albo $\mathrm{z}$ trudnością uruchomienia $\mathrm{w}$ odpowiednio krótkim czasie. Są to głównie rejony budów, eksploatacji surowców, lokalizacji oddziałów spółek międzynarodowych, jak również obszary odizolowane bądź słabo rozwinięte. W takich sytuacjach system satelitarnej łączności ruchomej stanowi doskonałą alternatywę dla innych systemów radiokomunikacyjnych.

Obecnie powstają sieci, które realizują nie tylko podstawowe usługi foniczne, ale także transmisję danych oraz inne rodzaje usług niefonicznych przy wykorzystaniu małych, przenośnych terminali. Stwarza to dobre warunki do tego, aby systemy satelitarne odgrywały znaczącą rolę w dalszym rozwoju radiokomunikacji ruchomej.

\section{INMARSAT wg [4]}

Organizacja INMARSAT (ang. ,INternational MARitime SATellite Organization”) powstała w 1979 roku z inicjatywy Międzynarodowej Organizacji Morskiej IMO (ang. ,International Maritime Organization”).
Polska była jednym z 40 państw-założycieli. Obecnie INMARSAT stowarzysza 75 państw.

Początkowo głównym celem organizacji było stworzenie globalnego systemu łączności ruchomej dla użytkowników morskich. Cel ten osiągnięto po uruchomieniu sieci standardu INMARSAT-A, która rozpoczęła pracę operacyjną w 1982 roku. W związku $\mathrm{z}$ postępem technologicznym, który nastapił od tamtego czasu i umożliwił m. in. znaczną redukcję wymiarów i masy urządzeń końcowych (terminali), a także obniżenie ich ceny, możliwe stało się wykorzystanie tej samej koncepcji łączności także w powietrzu i na lądzie. Znalazło to odzwierciedlenie w opracowaniu przez INMARSAT standardów łączności dostosowanych do nowych obszarów zastosowań.

INMARSAT jest również jednym z najważniejszych elementów Światowego Morskiego Systemu Alarmowania w Niebezpieczeństwie i dla Zapewnienia Bezpieczeństwa GMDSS (ang. „Global Maritime Distress and Safety System”). Umożliwia rozsyłanie i odbieranie wiadomości SafetyNET i FleetNET oraz retransmisję wiadomości NAVTEX (ostrzeżenia przybrzeżne) [23].

INMARSAT jest organizacją rozwijającą się bardzo dynamicznie. Globalny charakter oferowanych usług oraz ich różnorodność zapewnia jej bardzo dobrą pozycję na rynku usług radiokomunikacji ruchomej. Obserwowany wzrost liczby użytkowników systemu oraz postęp technologiczny umożliwiający redukcję wielkości i masy terminali prowadzą do obniżenia kosztów realizacji połączeń oraz kosztów zakupu terminali. Wraz ze wzrostem liczby użytkowników system wymaga dalszego zwiększania jego pojemności oraz modernizacji segmentu satelitarnego - obecnie wprowadzane są do użytku satelity IV generacji.

\subsection{Struktura systemu INMARSAT}

\subsubsection{Segment kosmiczny}

Segment satelitarny systemu INMARSAT to konstelacja czterech satelitów podstawowych umieszczonych na orbicie geostacjonarnej (rys. 5), które obsługują następujące cztery rejony:

- AOR-W (ang. „Atlantic Ocean Region-West”) - rejon Oceanu Atlantyckiego - Zachodni (pozycja satelity: $54^{\circ} \mathrm{W}$ )

- AOR-E (ang. „Atlantic Ocean Region-East”) rejon Oceanu Atlantyckiego - Wschodni (pozycja satelity: $15,5^{\circ} \mathrm{W}$ )

- IOR (ang. „Indian Ocean Region”) - rejon Oceanu Indyjskiego (pozycja satelity: 64,5 $\mathrm{E}$ )

- POR (ang. „Pacific Ocean Region”) - rejon Oceanu Spokojnego (pozycja satelity: $178^{\circ} \mathrm{E}$ ).

Oprócz wymienionych satelitów podstawowych w skład segmentu satelitarnego systemu wchodzą również satelity rezerwowe, które $\mathrm{w}$ razie awarii lub uszkodzenia satelity podstawowego przejmują jego funkcje. 


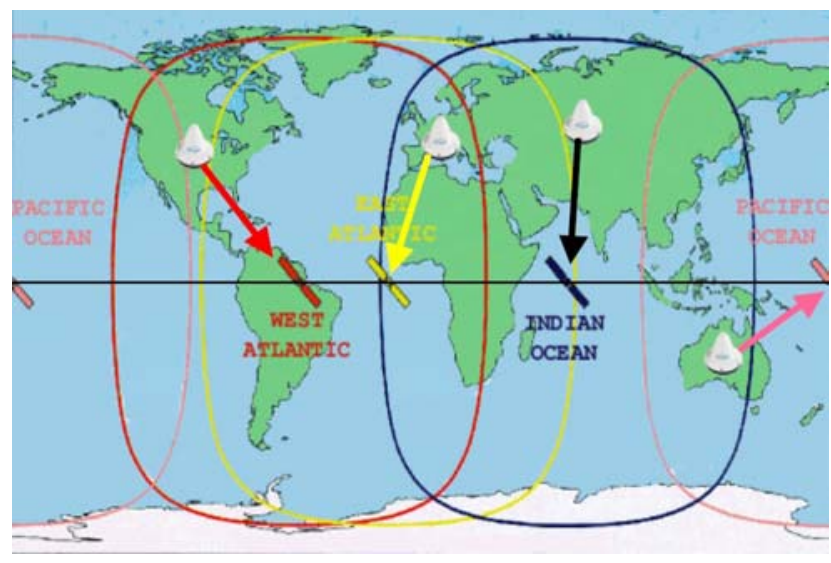

Rys. 5. Segment kosmiczny systemu INMARSAT wg [10]

Podział rejonu Oceanu Atlantyckiego na dwa odrębne rejony obsługiwane przez dwa satelity nastąpiło w 1990 roku, ze względu na występujące tam największe nasilenie ruchu oraz dla zapewnienia pełnego globalnego pokrycia, którego nie dało się uzyskać w poprzedniej konfiguracji systemu przy wykorzystaniu jedynie trzech satelitów. System nie zapewnia pokrycia obszarów podbiegunowych - zasięg działania systemu to pas od $70^{\circ}$ szerokości geograficznej południowej do $70^{\circ}$ szerokości geograficznej północnej.

Satelity odbierają sygnały nadawane przez segment naziemny, wzmacniaja je, przesuwają do właściwego pasma częstotliwości i transmitują w kierunku Ziemi. Łączność pomiędzy satelitą a częścią ruchomą segmentu naziemnego (terminalami ruchomymi) odbywa się $\mathrm{w}$ paśmie $\mathrm{L}(1,6 \mathrm{GHz}$ do satelity, $1,5 \mathrm{GHz} \mathrm{z}$ satelity), natomiast pomiędzy satelitą a częścią stałą segmentu naziemnego $\mathrm{w}$ paśmie $\mathrm{C}$ (6 GHz do satelity, $4 \mathrm{GHz} z$ satelity).

Do segmentu satelitarnego zalicza się także stacje nadzorujące i sterujące pracą satelitów (ang. „Telemetry, Tracking and Control Stations”). Ich zadaniem jest utrzymanie właściwego położenia satelitów, ustawianie pożądanych parametrów urządzeń telekomunikacyjnych umieszczonych na satelitach oraz zdalne pomiary parametrów technicznych satelitów (poziom paliwa, obciążenie energetyczne, itp.).

\subsubsection{Segment naziemny}

\subsubsection{Terminale ruchome}

Najbardziej widocznym elementem segmentu naziemnego z punktu widzenia użytkownika jest urządzenie końcowe nazywane terminalem ruchomym lub stacją naziemna. Terminal tworzą: antena, część radiowa, modem, urządzenia obróbki sygnału i urządzenia interfejsu użytkownika, czyli aparat telefoniczny, faks lub też złącze do przyłączenia terminalu komputerowego bądź innego urządzenia mogącego stanowić źródło danych. Rozróżnia się: statkowe stacje naziemne SES (ang. „Ship Earth Station”) oraz ruchome stacje naziemne MES (ang. „Mobile Earth Station").
Terminale mogą znacznie różnić się do siebie pod względem konstrukcji, w zależności od standardu w jakim pracują jak i producenta urządzenia, jednak realizują te same funkcje:

- umożliwiają korzystanie z typowych dla standardu urządzeń interfejsu użytkownika

- „nasłuchują" kanał sygnalizacyjny w celu wychwycenia próby nawiązania połączenia

- w przypadku odebrania sygnału wywołania nastrajają się na właściwy kanał w celu realizacji połączenia

ponadto w przypadku inicjalizacji połączenia przez użytkownika terminalu:

- umożliwiają dokonania wyboru lądowej stacji naziemnej LES, za pośrednictwem której będzie realizowane połączenie

- $\quad$ wysłają do wybranej stacji LES żądanie przydziału kanału

- umożliwiają wybór adresata połączenia i przesyłają wybrany numer do stacji LES.

Liczba terminali systemu uzależniona jest jedynie od liczby użytkowników. Wszystkie terminale pracujące w systemie stanowią część ruchomą segmentu naziemnego i nie są przypisane na stałe do żadnego $\mathrm{z}$ wymienionych czterech rejonów (AOR-W, AOR-E, IOR, POR).

\subsubsection{Lądowe stacje naziemne LES}

Lądowe stacje naziemne LES (ang. „Land Earth Station") nazywane są również brzegowymi stacjami naziemnymi CES (ang. „Coast Earth Station”). Druga nazwa pochodzi z czasów, gdy INMARSAT zajmował się wyłącznie łącznością morską. W konstrukcji stacji LES występują takie same elementy, jak w terminalu ruchomym, tzn. antena, nadawczo-odbiorcza radiowa część urządzenia, modemy i powiązane $\mathrm{z}$ nimi tzw. wyposażenie kanałowe oraz właściwe tylko dla stacji LES urządzenia kontroli dostępu i nadzoru ACSE (ang. ,Access Control and Supervisory Equipment"). Stacja LES zamiast w interfejs użytkownika wyposażona jest $\mathrm{w}$ interfejs do sieci publicznej (w zależności od standardu może to być sieć telefoniczna, teleksowa, pakietowa bądź kilka z nich), stanowi więc bramę łączącą sieć systemu INMARSAT z sieciami publicznymi.

Stacja LES umożliwia użytkownikowi terminalu ruchomego nawiązanie połączenia $\mathrm{z}$ dowolnym abonentem sieci publicznej znajdującym się w dowolnym miejscu świata. Realizacja takiego połączenia jest możliwa, jeżeli tylko istnieją łącza telefoniczne pomiędzy krajem docelowym a krajem, w którym zlokalizowana jest stacja LES. Dodatkowo użytkownik terminalu ruchomego może skorzystać z pośrednictwa dowolnej stacji LES. Pozwala to użytkownikom wybierać stacje LES w zależności od punktu docelowego jak też ze względu na wysokość opłat pobieranych przez operatora danej stacji. Sprawia to, że wewnątrz systemu istnieje konkurencja pomiędzy 
operatorami poszczególnych stacji LES, którzy poprzez atrakcyjność swojej oferty mogą zachęcać użytkowników do korzystania z ich stacji. Możliwe jest również nawiązanie połączenia pomiędzy dwoma terminalami ruchomymi systemu.

Dzięki stacjom LES również abonenci sieci publicznej mają możliwość nawiązywania połączeń z terminalami ruchomymi, jednak $\mathrm{w}$ tym przypadku abonent nie ma możliwości wyboru stacji. Wyboru tego dokonuje krajowy operator telekomunikacyjny, kierujący ruch poprzez własne stacje LES bądź przez stacje operatorów z którymi zawarł odpowiednie porozumienia.

W Polsce usługi w systemie INMARSAT oferuje Centrum Usług Satelitarnych TP S.A. mieszczące się w Psarach koło Kielc, które jest operatorem dwóch naziemnych stacji satelitarnych standardu INMARSAT-C. Stacje te uruchomiono w dniu 1 października 1997. Aktualnie współpracują one $\mathrm{z}$ satelitami INMARSAT trzeciej generacji: F2 $15.5^{\circ} \mathrm{W}$ we wschodnim rejonie Oceanu Atlantyckiego (AOR-E) oraz F1 $64^{\circ} \mathrm{E}$ w rejonie Oceanu Indyjskiego (IOR) [28].

Dostęp z sieci publicznej do sieci INMARSAT następuje poprzez wybór odpowiedniego numeru kierunkowego. INMARSAT uzyskał przydział numerów kierunkowych (ang. „Country Code”) dla poszczególnych rejonów na takich samych zasadach jak państwa.

Są to następujące numery (kolejno dla rejonów AORE, POR, IOR, AOR-W):

- dla publicznej sieci telefonicznej: 871, 872, 873,874

- dla publicznej sieci teleksowej: 581, 582, 583, 584

- dla publicznej sieci pakietowej: 1111, 1112, $1113,1114$.

Pozostałe funkcje, jakie pełni lądowa stacja naziemna LES, to:

- nasłuchiwanie kanałów sygnalizacyjnych i wychwytywanie wywołań oraz informacji adresowanych do danej stacji

- automatyczna weryfikacja uprawnień terminali wywołujących stację do korzystania z systemu i akceptacja wywołań tylko od uprawnionych użytkowników

- wymiana informacji sygnalizacyjnej z centralą międzynarodową oraz z innymi elementami segmentu naziemnego, w tym żądanie przydziału kanału satelitarnego

- zestawianie połączeń pomiędzy abonentami sieci publicznej a użytkownikami terminali ruchomych lub pomiędzy użytkownikami terminali ruchomych

- w ramach zestawiania połączeń m. in. dostrajanie modemów nadawczo-odbiorczych do przydzielonego kanału
- rejestracja czasu połączeń i innych danych niezbędnych dla wystawienia rachunku dla użytkownika.

\subsubsection{Stacje koordynujące sieci}

Podstawowym zadaniem stacji koordynującej sieci NCS (ang. „Network Coordination Station”) jest zarządzanie w czasie rzeczywistym przydziałem kanałów satelitarnych dla poszczególnych połączeń. Generalną zasadą we wszystkich standardach INMARSAT jest to, że kanał przydzielany jest poszczególnym użytkownikom tylko na czas trwania połączenia. Pozwala to na optymalne wykorzystanie widma częstotliwości i mocy satelitów. W konsekwencji użytkownik płaci tylko za rzeczywiste wykorzystanie systemu. Jedna stacja koordynująca obsługuje $\mathrm{z}$ reguły przydział kanałów satelitarnych na jednym satelicie i dla jednego standardu. W celu realizacji przydziału kanałów stacja koordynująca odbiera informacje sygnalizacyjne ze wszystkich lądowych stacji naziemnych LES pracujących w danym rejonie. Informacje te stanowią pewnego rodzaju zamówienia na określone kanały. W zależności od istniejących możliwości stacja NCS przydziela odpowiedni kanał lub wysyła do stacji LES występującej o jego przyznanie i terminalu chcącego nawiązać połączenie informację o braku możliwości realizacji tego połączenia z odpowiednim kodem pozwalającym rozpoznać przyczynę jego odrzucenia.

\subsection{Standardy systemu INMARSAT}

Początkowo INMARSAT był systemem dedykowanym przede wszystkim na potrzeby żeglugi morskiej. Zasadniczym celem pomysłodawców i realizatorów projektu było zapewnienie możliwości nawiązania łączności z lądem przez każdy statek znajdujący się na pełnym morzu.

Najstarszym standardem systemu jest INMARSAT-A uruchomiony w 1982 roku. Standard ten zapewnia transmisję głosu, usługi teleksowe i faksowe oraz transmisję danych. Jest to jedyny standard analogowy (zastosowano w nim modulację FM) [9]. Pozostałe standardy są w pełni cyfrowe. $Z$ powodu dużych rozmiarów urządzeń (antena o średnicy ok. 1 m wyposażona w mechaniczny układ stabilizacji położenia), ich masy (ok. 100 kg), jak i wysokich kosztów ich zakupu terminale tego standardu instalowane były głównie na dużych statkach i platformach wiertniczych. W 1993 roku w celu zastapienia standardu INMARSAT-A został wprowadzony standard INMARSAT-B, który oferuje te same usługi ale realizowane w technice cyfrowej.

Doskonałe rozwiązania systemowe oraz wysoka jakość funkcjonowania wywołały zainteresowanie systemem również użytkowników lądowych. Wyjście systemu poza sektor morski nastąpiło w roku 1991 wraz z wprowadzeniem standardu INMARSAT$\mathrm{C}$, który nie umożliwia nawiązywania połączeń 
telefonicznych a jedynie dwukierunkową transmisję danych z przepływnością 600 bit/s. W 1992 roku uruchomiono przeznaczony dla lotnictwa INMARSATAERO. Od tego momentu to głównie zastosowania lądowe wymuszały powstawanie nowych odmian systemu o coraz bardziej wyrafinowanych możliwościach technicznych. Zaowocowało to wprowadzaniem kolejnych standardów, m. in.: M (1992), D/D+ (1995), E/E+, mini-M (1996), M4 (GAN, ISDN) (1999), R-BGAN (2002), BGAN (2004), Fleet-33/55/-77 (w nawiasach podano rok uruchomienia danego standardu).

\subsection{Standard INMARSAT-C}

Jak wspomniano standard ten zapewnia jedynie dwukierunkową transmisję danych $\mathrm{w}$ trybie simpleksowym z przepływnością 600 bit/s. Kolejną specyficzną dla tego systemu właściwością jest to, że pracuje on $\mathrm{w}$ trybie „przechowaj i przekaż” (ang. „store-andforward"). Oznacza to, że informacja po jej nadaniu z terminalu lub z sieci publicznej dociera do lądowej stacji naziemnej LES, gdzie jest zapisywana w bazie danych i oczekuje w kolejce na nadanie do odbiorcy. Czas oczekiwania w kolejce zależy od aktualnego obciążenia stacji i może wahać się w zakresie od kilkunastu sekund do kilkunastu minut. Lądowa stacja naziemna może ponadto dokonywać translacji przesyłanych wiadomości do pożądanego formatu np. faksu, teleksu lub e-maila.

Opisane powyżej cechy standardu nie wykluczają realizacji połączeń $\mathrm{w}$ obu kierunkach, tzn. $\mathrm{z}$ sieci publicznej do terminalu ruchomego i odwrotnie lub pomiędzy dwoma terminalami ruchomymi, jednak uniemożliwiaja prowadzenie konwersacji pomiędzy nadawcą a odbiorcą.

INMARSAT-C oprócz transmisji danych udostępnia wiele innych serwisów [24]:

rozsyłanie i odbieranie wiadomości SafetyNET i FleetNET w ramach Światowego Morskiego Systemu Alarmowania w Niebezpieczeństwie i dla Zapewnienia Bezpieczeństwa GMDSS (ang. „Global Maritime Distress and Safety System")

- APR (ang. „Automatic Positioning Reporting") - automatyczne ustalanie pozycji i przesyłanie raportów pozycyjnych wg GPS

- Polling - sprawdzanie, które terminale są aktualnie zalogowane i aktywne

- SCADA (ang. „Supervisory Control And Data Acqusition") - sterowanie nadrzędne i zbieranie danych.

Praca w trybie „store-and-forward” może okazać się niezbyt korzystna dla niektórych zastosowań, zwłaszcza wymagających pracy w czasie rzeczywistym lub pracy konwersacyjnej jednak nie stanowi przeszkody $\mathrm{w}$ przypadku przesyłania danych diagnostycznych z systemu sterowania pojazdu.
Niewątpliwymi zaletami tego standardu są bardzo małe rozmiary terminali oraz małe rozmiary anten o wielokierunkowej charakterystyce, co eliminuje konieczność nakierowywania ich na satelitę. Najbardziej typowo wyglądająca antena standardu INMARSAT-C to stożek o średnicy podstawy ok. $20 \mathrm{~cm}$ i wysokości ok. $30 \mathrm{~cm}$. Najnowsze konstrukcje anten to krążki o średnicy ok. $12 \mathrm{~cm}$ i wysokości ok. $3 \mathrm{~cm}$.

\section{Zastosowany terminal satelitarny}

W ramach projektu badawczego zakupiono terminal satelitarny TT-3026L easyTrack duńskiej firmy Thrane \& Thrane A/S (rys. 6), który pracuje w systemie INMARSAT mini-C.

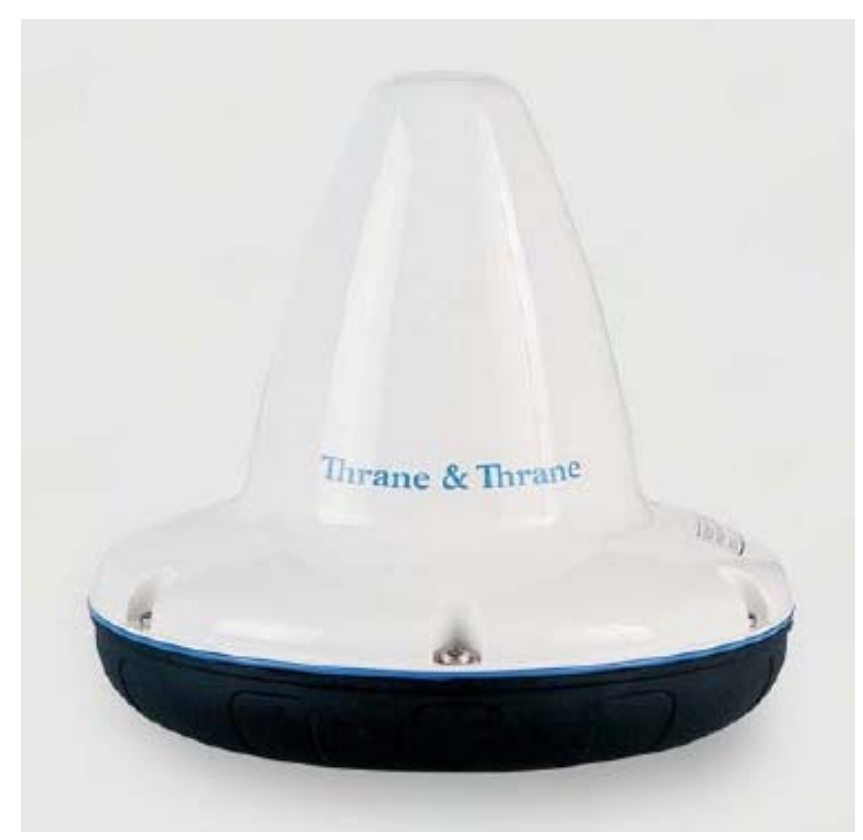

Rys. 6. Terminal satelitarny TT-3026L easyTrack wg [11]

Poniżej zestawiono wybrane parametry techniczne terminalu wg [11]:

- napięcie zasilania: $(10,5 \div 32) \mathrm{V} \mathrm{DC}$

- pobór mocy: max. $32 \mathrm{~W}$

- temperatura pracy: $-35{ }^{\circ} \mathrm{C} \div 55^{\circ} \mathrm{C}$

- wymiary: $\varnothing=163 \mathrm{~mm}, \mathrm{H}=146 \mathrm{~mm}$

- masa: $1,1 \mathrm{~kg}$.

Omawiany terminal umożliwia transmisję danych $\mathrm{z}$ prędkością $600 \mathrm{bit} / \mathrm{s}$ do/z pojazdu poruszającego się z prędkością nie przekraczającą wartości $140 \mathrm{~km} / \mathrm{h}$. Terminal ten ma wbudowany 12-kanałowy odbiornik systemu GPS, co umożliwia określenie pozycji pojazdu z dokładnością do $15 \mathrm{~m}$, jego prędkości i kursu oraz czasu UTC (ang. „Universal Coordinated Time”). Dane te odświeżane są co $1 \mathrm{~s}$. Transmisja danych do/z terminalu realizowana jest za pośrednictwem interfejsu RS-232. 


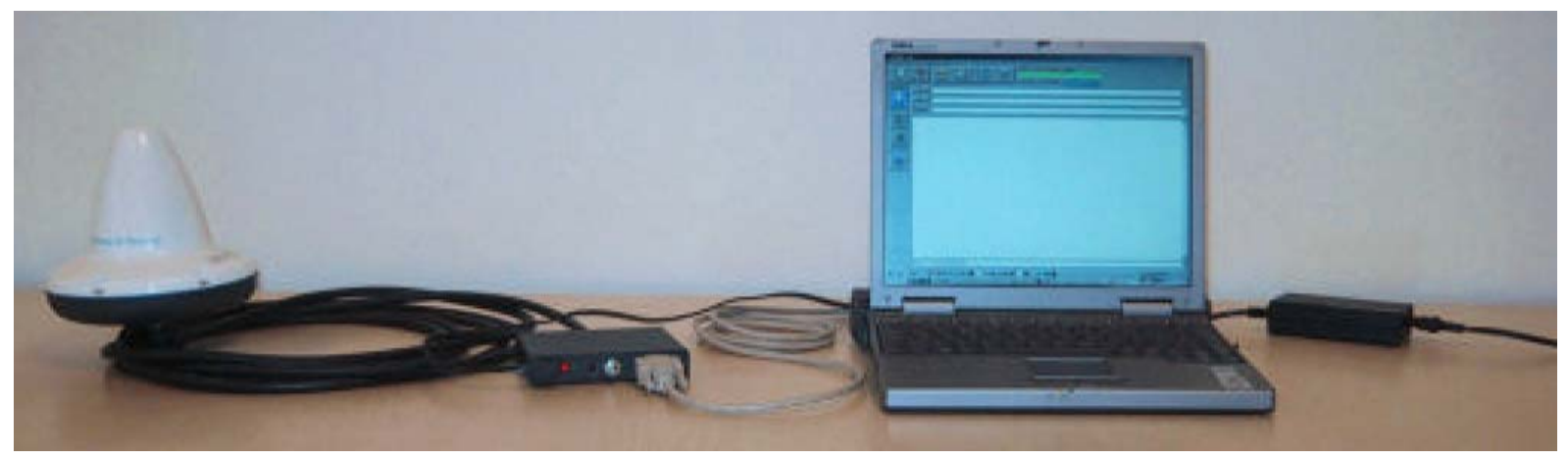

Rys. 7. Układ laboratoryjny do testowania transmisji satelitarnej wg [11] (1- terminal satelitarny TT-3026L easyTrack, 2 skrzynka podłączeniowa TT-3616B, 3 - laptop)

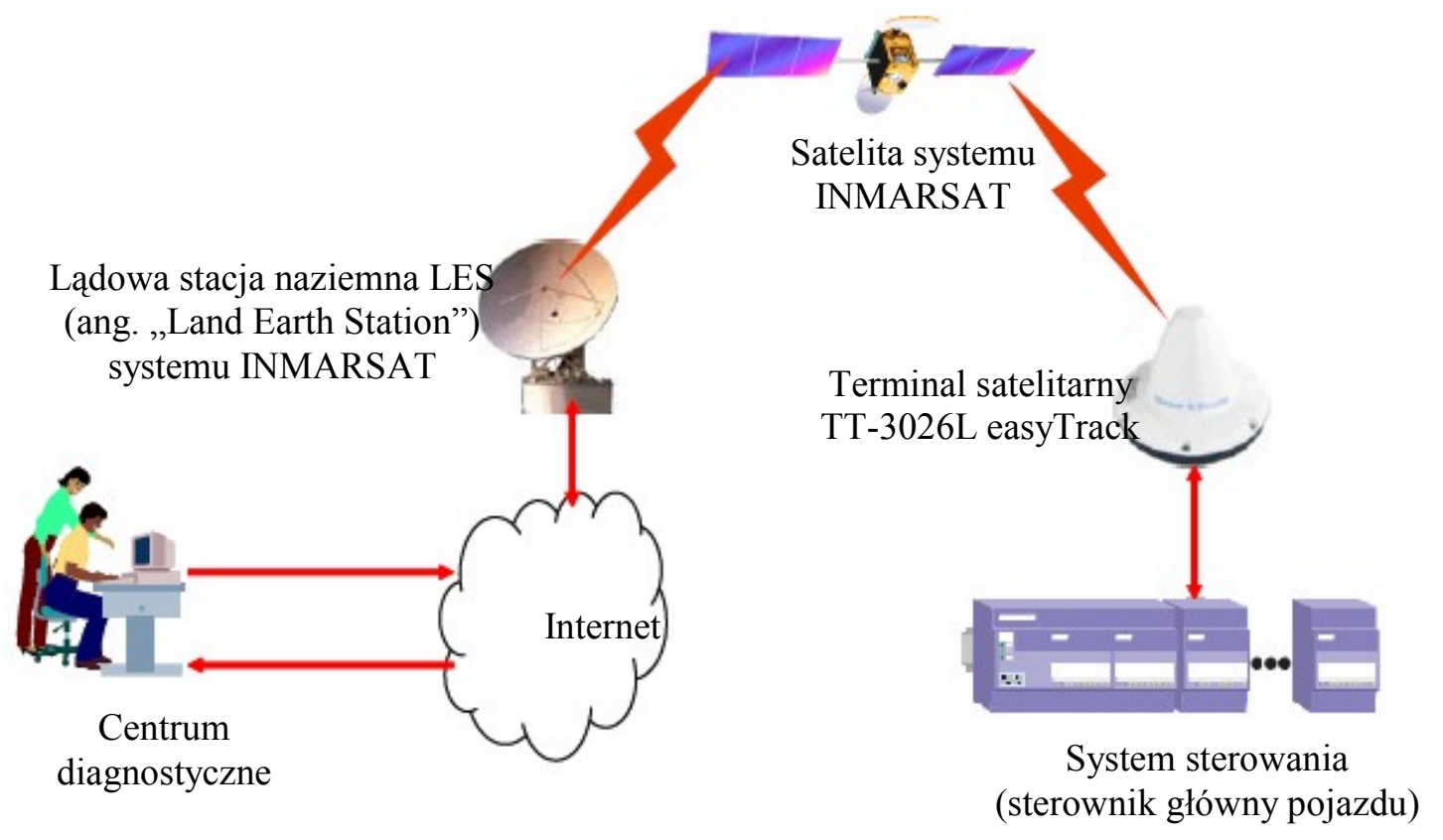

Rys. 8. Tor transmisji danych diagnostycznych z pojazdu szynowego wg [13]

\section{Struktura systemu przesyłania danych}

$\mathrm{Na}$ rys. 7 przedstawiono tor laboratoryjny wykorzystywany do testowania transmisji satelitarnej. Za jego pośrednictwem możliwe jest przesyłanie danych diagnostycznych jako załączników do listów poczty elektronicznej wysyłanych z wykorzystaniem dostarczonego przez producenta terminalu satelitarnego programu „easyMail”.

\section{Oprogramowanie}

Oprogramowanie sterownika głównego pojazdu musi uwzględniać algorytm generowania danych diagnostycznych i przesyłania ich po łączu szeregowym do terminalu satelitarnego w celu transmisji do centrum diagnostycznego. Kolejne paczki danych będą dostarczane do komputera pełniącego rolę centrum diagnostycznego jako załączniki poczty elektronicznej. Oprogramowanie zainstalowane na tym komputerze musi konwertować dane zawarte w załącznikach na wartości poszczególnych danych diagnostycznych a następnie dokonać ich analizy, prezentacji i archiwizacji.

\section{Podsumowanie i wnioski}

Zastosowanie łącz satelitarnych umożliwia transmisję danych diagnostycznych z pojazdu szynowego niezależnie od miejsca, w którym on się znajduje. Z bardzo dużą dozą prawdopodobieństwa można prognozować, że transmisja satelitarna będzie odgrywać coraz większą rolę $\mathrm{w}$ telekomunikacji a postęp $\mathrm{w}$ technologii budowy urządzeń do transmisji satelitarnych spowoduje spadek cen ich zakupu oraz zmniejszenie ich rozmiarów. Można oczekiwać również zwiększenia przepustowości łącz satelitarnych oraz obniżenia kosztów przesyłu danych. W związku z powyższym zastosowanie transmisji satelitarnej do transmisji danych diagnostycznych $\mathrm{z}$ pojazdów szynowych jest rozwiązaniem przyszłościowym. 


\section{Literatura}

[1] Amanowicz M.: Satelitarne systemy radiokomunikacji ruchomej, Przeglad telekomunikacyjny, $\mathrm{Nr}$ 5-6/1995.

[2] Bem D. J.: Rozwój radiokomunikacji, Przegląd telekomunikacyjny, $\mathrm{Nr}$ 1/2003.

[3] Haba M.: Programy wspomagajace uruchamianie mikroprocesorowych systemów sterowania $w$ pojazdach szynowych, Pojazdy Szynowe, $\mathrm{Nr} 2 / 2007$.

[4] Kmieciak J.: INMARSAT - globalny system satelitarnej łaczności ruchomej, Przeglad telekomunikacyjny, Nr 5-6/1995.

[5] Modelski J., Kurek K.: Perspektywy rozwoju systemów taczności satelitarnej, Politechnika Warszawska - Wydzial Elektroniki i Technik Informacyjnych - Instytut Radioelektroniki, Warszawa, Październik 2004 (dokument PDF pobrany ze strony: www.urtip.gov.pl).

[6] Nawrocki W.: Rozproszone systemy pomiarowe, WKE, Warszawa 2006.

[7] Nawrocki W.: Komputerowe systemy pomiarowe, WKE, Warszawa 2002.

[8] Ryzenko J., Badurska A., Kobierzycka A.: Kierunki rozwoju systemów satelitarnych: łaczność satelitarna, Raport I fazy projektu Foresight „Przyszłość technik satelitarnych $w$ Polsce Dziś-Jutro-Pojutrze" prowadzonego przez Polskie Biuro ds. Przestrzeni Kosmicznej, Styczeń 2007 (dokument PDF pobrany ze strony: www.kosmos.gov.pl).

[9] Wesolowski K.: Systemy radiokomunikacji ruchomej, WKE, Warszawa 2006.

[10] Thrane \& Thrane A/S: TT-3026L/M easyTrack. Getting Started.

[11] Thrane \& Thrane A/S: TT-3026L/M/S easyTrack Transceiver. Installation Manual.
[12] Thrane \& Thrane A/S: TT-3026L/M/S easy Track Transceiver. User/Operators Manual.

[13] Thrane \& Thrane A/S: Mini-C SCADA Integration Manual.

[14] midob.republika.pl/wyprawy.html

[15] pl.wikipedia.org/wiki/Echo_1

[16]www.firstscience.com/home/articles/machines/sol ar-sailing_51134.html

[17] pl.wikipedia.org/wiki/Eksploracja_kosmosu

[18] pl.wikipedia.org/wiki/Intelsat

[19] pl.wikipedia.org/wiki/Sputnik

[20] pl.wikipedia.org/wiki/Telstar_1

[21] pl.wikipedia.org/wiki/TIROS ${ }^{-1}$

[22]www.eduskrypt.pl/czy ziemia jest bezpieczna wyklad_na_politechnice_warszawskiej-info6098.html

[23] www.fkn.pl/4,3694,1357627,1,3,artykul.html

[24] www.heading.enter.net.pl/inmarsat.htm

[25] www.inmarsat.com

[26] www.space50.net/sputnik.html

[27]www.polskieradio.pl/nauka/wszechswiat/artykul1 7439. html

[28] www.psary.tpsa.pl

[29] www.sciaga.pl/tekst/4904-5zdobywanie_kosmosu_przez_czlowieka

[30] www.thrane.com

[31]www.wynalazki.mt.com.pl/joomla/index.php?opti on $=$ com_content\&task $=$ view\&id $=444 \&$ Itemid $=51$ 